\title{
Study of factors influencing behavioral stereotypes regarding health in students of medical specialties
}

\author{
E. K. Fedorishcheva ${ }^{1}$, I. A. Gareeva², K. V. Kosilov
}

1Pacific State Medical University, 2 Ostryakova Ave., Vladivostok 690002, Russian Federation

2Pacific State University, 136 Tikhookeanskaya str., Khabarovsk, Russian Federation

${ }^{3}$ Far Eastern Federal University, Vladivostok, Russian Federation

DOI: $10.18255 / 2412-6519-2020-3-286-299$

Research Article

Full text in Russian

This article, from the standpoint of a structural-functional approach, explores the influence of socio-economic, social, organizational, psychological factors of the educational space of a medical university on the choice of students' behavioral strategies in relation to health-saving behavior.

The results obtained indicate a low self-esteem by students of behavioral stereotypes regarding health. According to the data obtained, the average total variable quantitatively describing negative behavioral standards in the framework of the two-component model (stereotyping factors) is most strongly correlated with environmental factors such as disturbance in regular and rational nutrition, lack of comfortable living conditions and training, inaccessibility for various reasons of sports facilities, an uncomfortable class schedule and several others. The authors conclude that current models of beliefs about health, motivation-information-skills, planned behavior, subjective expected usefulness, motivation for protection, are poorly applicable to the studied category, which probably can be associated with a lack of propensity for introspection and reflection, rationalization of their own behavior, characteristic of student youth environment.

At the same time, a pilot study of the tendency to copy behavioral stereotypes regarding health made it possible to draw a preliminary conclusion that most students refer to the behavior of friends, university teachers, and to a lesser extent opinion leaders and parents as role models. These data can be the basis for further expanded study of the processes of formation of behavioral strategies in relation to health and analysis of the results in the light of ideas about socially acceptable behavior of a person as a result of learning and communicative impact on a person.

Keywords: students; educational space; environmental factors; health saving behavior; behavioral stereotypes; structural and functional approach; social processes

\section{INFORMATION ABOUT THE AUTHORS}

\begin{tabular}{|c|c|}
\hline Fedorishcheva E. K. & $\begin{array}{l}\text { E-mail: katrina.kosilova@yandex.ru } \\
\text { Assistant }\end{array}$ \\
\hline Gareeva Irina A. & $\begin{array}{l}\text { E-mail: gar_ia@mail.ru } \\
\text { Doc.Sc. (Sociology), Professor }\end{array}$ \\
\hline $\begin{array}{r}\text { Kosilov Kirill V. } \\
\text { (correspondence author) }\end{array}$ & $\begin{array}{l}\text { E-mail: oton2000@mail.ru } \\
\text { Doc. Sc. (Medicine), Professor }\end{array}$ \\
\hline
\end{tabular}

For citation: Fedorishcheva E. K., Gareeva I. A., Kosilov K. V. Study of factors influencing behavioral stereotypes regarding health in students of medical specialties // Social'nye i gumanitarnye znanija. 2020. Vol. 6, No 3. P. 286-299. (in Russ.)

(C) Fedorishcheva E. K., Gareeva I. A., Kosilov K. V., 2020

This is an open access article under the CC BY-NC-ND license (http://creativecommons.org/licenses/by-nc-nd/4.0/) 


\title{
Факторы влияния на поведенческие стереотипы в отношении здоровья у студентов медицинских специальностей
}

\author{
Е. К. Федорищева ${ }^{1}$, И. А. Гареева ${ }^{2}$, К. В. Косилов ${ }^{3}$
}

1Тихоокеанский государственный медицинский университет, пр-т Острякова, 2, Владивосток, 690002, Российская Федерация

2Тихоокеанский государственный университет, ул. Тихоокеанская, 136, Хабаровск, Российская Федерация ${ }^{3}$ Дальневосточный Федеральный университет, Владивосток, Российская Федерация

DOI: $10.18255 / 2412-6519-2020-3-286-299$

Научная статья

УДК 316.4.062-066

Полный текст на русском языке

В данной статье с позиций структурно-функционального подхода исследуется влияние социальноэкономических, социально-бытовых, организационных, психологических факторов образовательного пространства медицинского университета на выбор поведенческих стратегий студентов в отношении здоровьесберегающего поведения.

Согласно полученным данным, студенты оценили свои поведенческие стереотипы в 2,6 балла из 5 возможных. Средняя суммарная переменная, количественно описывающая негативные поведенческие стандарты в рамках двухкомпонентной модели (факторы-стереотипы), наиболее сильно коррелирует с такими средовыми факторами, как нарушение регулярного и рационального питания, отсутствие комфортных условий проживания и обучения, недоступность по различным причинам спортивных учреждений, неудобное расписание занятий и ряд других. На основании проведенного анализа был сделан вывод от том, что актуальные модели поведения в отношении здоровья слабо применимы к исследуемой категории, что, вероятно, может быть связано с отсутствием склонности к самоанализу и рефлексии, рационализации собственного поведения, характерным для студенческой молодежной среды.

В тоже время пилотное исследование склонности к копированию поведенческих стереотипов в отношении здоровья позволило сделать предварительный вывод о том, что большинство студентов называют в качестве образцов для подражания поведение друзей, преподавателей университета, в меньшей степени лидеров мнений и родителей. Эти данные могут стать основанием для дальнейшего расширенного изучения процессов формирования поведенческих стратегий в отношении здоровья и анализа полученных результатов в свете представлений о социально приемлемом поведении личности как результате научения и коммуникативном воздействии на личность.

Ключевые слова: студенты; образовательное пространство; здоровьесберегающее поведение; факторы среды; поведенческие стереотипы; структурно-функциональный подход; социальные процессы

ИНФОРМАЦИЯ ОБ АВТОРАХ

Федорищева Е. К. $\quad$ E-mail: katrina.kosilova@yandex.ru

Ассистент кафедры общественного здоровья и здравоохранения

Гареева Ирина Анатольевна

Email: gar_ia@mail.ru

Доктор социологических наук, профессор кафедры социальной работы и психологии

Косилов Кирилл Владимирович $\mid$ Email: oton2000@mail.ru

(автор для корреспонденции) Доктор медицинских наук, профессор департамента социальных наук

Для цитирования: Федорищева Е. К., Гареева И. А., Косилов К. В. Факторы влияния на поведенческие стереотипы в отношении здоровья у студентов медицинских специальностей // Социальные и гуманитарные знания. 2020. Том 6, № 3. С. 286-299.

(C) Федорищева Е. К., Гареева И. А., Косилов К. В., 2020

Статья открытого доступа под лицензией СC BY-NC-ND (http://creativecommons.org/licenses/by-nc-nd/4.0/) 


\section{Введение}

Изучение социальных процессов, происходящих в образовательном пространстве медицинских университетов и связанных с приобретением студентами профессиональных навыков и компетенций, принято проводить не только в рамках рассмотрения социально приемлемых форм поведения, но и через призму анализа проявлений негативных поведенческих стереотипов [1, с. 18-19; 2, с. 11; 3, с. 10]. Бихевиоральный подход к исследованию и интерпретации девиантного поведения личности и социальной группы, изложенный в трудах Э. Торндайка, Дж. Уотсона и Б. Скиннера, нашедший развитие в работах С. Пинкера, Л. Выготского, А. Бандуры, Ч. Осгуда, Ж. Фреско, Р. Мертона [4, с. 12-18; 5, с. 120 ; 6, с. 43-45] и ряда других авторов, предполагает рассмотрение асоциальных поведенческих алгоритмов, в частности, с позиций теории научения. Основной идеей такого подхода является представление о социально приемлемом и девиантном поведении личности и группы как результате приспособления к особенностям социальной среды, адаптации к ее постоянно меняющимся условиям [7, с. 156; 8. с. 303-307].

Терминологическое пространство заявленной темы содержит ряд близких, но не тождественных конструктов, смысловую нагрузку которых было бы уместно оговорить заранее. К поведенческим стереотипам в отношении здоровья мы, следуя сложившемуся в специальной литературе подходу, относим относительно устойчивые привычки или шаблоны, характерные для поведения респондентов, типичные формы реагирования на внешние или внутренние факторы, связанные с их физическим или психологическим статусом. Соответственно, негативные поведенческие стереотипы соответствуют поведенческому рисунку, или алгоритму, являющемуся потенциально вредным для здоровья, способному при сочетании с неблагоприятными обстоятельствами нанести ущерб физическому и психологическому благополучию индивида. В свою очередь, «деструктивные», или «разрушительные», стереотипы поведения, подразумевают акты или действия, наносящие прямой непосредственный вред здоровью, связанные с риском возникновения у респондента тяжелых заболеваний или даже летальным исходом. В то же время девиантные формы поведения могут отражать особенности развития индивида, специфику его когнитивных возможностей, своеобразие воспитания и образования и далеко не всегда коррелируют с социально неприемлемыми поступками и действиями. В свете сказанного поведенческая модель представляет более широкое, обобщающее понятие и соответствует определенному набору поведенческих стереотипов, форм шаблонного реагирования на те или иные социально-средовые факторы влияния.

Перспективной методологической основой изучения факторов нерационального поведения в отношении здоровья в студенческой среде представляется также структурно-функциональный подход, предполагающий исследование функциональных зависимостей между поведенческими стандартами в отношении здоровья и структурой институтов поддержания физического и психического здоровья в рамках образовательного пространства. Этот подход, на наш взгляд, позволил бы сформировать модель социального процесса, описывающую формирование различных негативных поведенческих стереотипов в отношении здоровья при воздействии широкого спектра средовых факторов [5, с. 120-122; 7, с. 156; 8, с. 103-105], и мог бы способствовать определению закономерности значимого социального процесса - приспособления студенческой молодежи к заданным условиям образовательного 
пространства - и выявить проблемные точки, деструктивные факторы, снижающие эффективность адаптации.

Использование структурно-функционального подхода предполагает оценку и углубленный анализ функциональных зависимостей между социальными средовыми факторами, непосредственно влияющими на процесс принятия тех или иных поведенческих решений, связанных со здоровьем, с одной стороны, а также имеющимися и формируемыми в социальной группе поведенческими стереотипами - с другой. Анализ подобных зависимостей ограничивается рамками социального института - образовательного пространства медицинского университета, структурированного согласно своему функциональному предназначению на различные подразделения: собственно учебные, хозяйственно-бытовые, медицинские, вспомогательные. С позиций структурно-функционального подхода наиболее конструктивным для достижения заявленной цели представляется формирование двухкомпонентной модели, одна из частей которой представлена несколькими совокупностями социально-средовых факторов, включающих функционально однородные элементы (административно-организационные, социально-психологические, медицинские, социально-бытовые, экономические), другая - устойчивыми поведенческими стереотипами, связанными со здоровьем и здоровьесбережением. Корреляционный анализ функциональных зависимостей между отдельными доменами, количественно описывающими структуру, характеристики, реализуемые функции образовательного пространства, и основными поведенческими шаблонами студентов позволил бы объективизировать характеристики социального процесса их адаптации к новым социальным условиям и оценить его успешность, эффективность. Методология функционализма, разумеется, не ограничивается эвристическим поисковым подходом, а предполагает и конкретно-научный и философский уровни изучения социальных процессов. Если исходный уровень может быть представлен составлением репрезентативной выборки, опросом и анкетированием, позволяющими определить наличие и субъективную значимость тех или иных социальных факторов, то конкретно-научный уровень может быть представлен корреляционным анализом полученного массива данных для выявления статистически значимых взаимосвязей, оценки «вклада» каждой переменной в конечный результат.

Попытки теоретического осмысления процессов, определяющих поведение представителей различных социальных страт в отношении здоровья, представлены моделями «убеждений о здоровье», «мотивации-информации-навыков», теориями запланированного поведения, субъективной ожидаемой полезности, мотивации защиты. В литературе представлена также попытка осмысления некоторых аспектов здоровьесберегающего поведения с позиций социально-когнитивной теории. Согласно последней, поведенческие стереотипы, имеющие отношение к здоровью, реализуются в том случае, когда индивид считает, что в состоянии не только их реализовать, но и осуществить эффективный контроль достижения конечного результата [9, с. 105-107]. Близки к данной теории и основные положения теории запланированного поведения, а также модель убеждений о здоровье, предполагающие, что поведенческая стратегия индивида в отношении здоровья складывается из убеждений о пользе и вреде и определенных поступков, способности (действительной или мнимой) к достижению поведенческих целей и намерения их реализовать. Конечное действие или бездействие определяется базовыми установками, субъективными индивидуальными нормами и воспринимаемым поведенческим контролем, который используется как индикатор эффективности поведения [10, с. 65-66; 11, с. 110-113]. 
Впрочем, данная группа идей и представлений в настоящее время справедливо подвергается критике в связи с множеством эмпирических данных о несоответствии между намерениями, предполагаемым и реальным поведением.

Близкая к перечисленным модель информации-мотивации-поведенческих решений постулирует, что поведение, связанное с рисками для состояния здоровья, определяется, соответственно, тремя основными факторами: объемом имеющейся у индивида информации, наличием достаточных мотиваций, имеющимися поведенческими стереотипами [13, с. 103-105]. Ее авторы допускают, что информированный (и способный осмыслить эту информацию) человек в процессе жизнедеятельности и приобретения новых знаний изменяет поведенческие стереотипы в направлении здоровьесбережения, осваивает сложные, но более эффективные поведенческие стратегии. Однако экспертное сообщество довольно осторожно относится к основным идеям, заложенным в данной теории, учитывая существенное упрощение и формализацию изучаемых процессов и достаточно небольшой спектр оцениваемых факторов.

Популярная в социологической среде теория субъективной ожидаемой полезности во главу угла ставит представление о том, что ожидаемый индивидом полезный эффект от сочетания всех действий, направленных на здоровьесбережение, и определяет конфигурацию его поступков [10, с. 65-66; 14, с. 1-4.]. Терминологическое пространство, которым оперирует теория, включает понятие мультипликативного правила, то есть определение индивидом соотношения разных факторов по уровню их вклада в субъективную «полезность» или «вред» для здоровья. Ее основной концептуальный посыл и заключается в утверждении о постоянном сознательном и подсознательном анализе индивидом соотношения, с одной стороны, психоэмоционального и интеллектуального удовольствия, позитивных эмоций, которые сопровождают определенные действия, с другой - вероятных негативных последствий этих действий. Относительно узкий спектр рассматриваемых факторов авторы пытались компенсировать введением в концепцию понятия «уверенности»индивидуального представления о шансах на достижение успеха - и ряда других расширений. Наконец, теория мотивации защиты предполагает оценку поведенческих стереотипов в отношении здоровья как адаптивную копинг-стратегию, определяемую субъективным сопоставлением индивидом опасностей и возможностей их предотвращения [15, с. 408-411]. Под опасностями подразумеваются заболевания разной степени тяжести, под возможностями преодоления - эффективность приспособительного поведения и оценка своих возможностей в этом смысле.

Каждая из перечисленных теорий и концепций, безусловно, заслуживает внимания и вносит вклад в понимание процессов приспособительного поведения, в частности, студентов к новым социальным пространствам с точки зрения отношения к здоровью и здоровьесбережению. Тем не менее целый ряд проведенных метаанализов, включая фундаментальное обзорное исследование Е. И. Рассказовой [16, с. 83], позволили определить средний, а иногда и слабый уровень детерминированности изучаемых социальных процессов указанным в упомянутых концепциях спектром факторов, что делает необходимым как минимум их дальнейшее уточнение, дополнение, а возможно, и пересмотр некоторых постулируемых положений, не находящих прямого подтверждения.

Проблемы осмысления и понимания процессов адаптации студентов к образовательному пространству и анализа факторов, негативно влияющих на приспособительные стратегии, в настоящее время стоят довольно остро [17, с. 82; 18, с. 127-129; 
19, с. 156]. Это связано прежде всего с насущной потребностью здравоохранения Дальнего Востока России в притоке высококвалифицированных молодых специалистов, обладающих к моменту окончания университета всеми навыками и компетенциями, необходимыми для работы в сложных условиях региона [20, с. 17].

Обучение медицинским специальностям в профильных университетах имеет ряд существенных особенностей и сопряжено со значительными материальными издержками, наиболее продолжительно по времени по сравнению с другими профессиональными направлениями и сопровождается интенсивными нагрузками на когнитивною сферу, необходимостью длительного ежедневного пребывания в специальных университетских аудиториях, оснащенных лабораторным, диагностическим, мультимедийным оборудованием, симуляторами физиологических процессов, макро- и микропрепаратами [21, с. 41-44]. Эффективность медицинского образования, как и любого другого, связана с множеством средовых социальноэкономических, бытовых, психологических, организационно-административных и иных факторов [22, с. 281; 23, с. 16-18]. Тем не менее большинство авторов, занимавшихся изучением этих вопросов в последние годы, сходится во мнении, что одним из наиболее важных, если не ключевых параметров, определяющим качество медицинского образования, является состояние здоровья студентов, во многом связанное с поведенческими стереотипами.

В доступной литературе высказывается мнение, согласно которому высокий уровень хронической соматической патологии у студентов-медиков может быть взаимосвязан не только с интенсивными психологическими, интеллектуальными и физическими нагрузками, сопровождающими образовательный процесс, и «шлейфом» подростковой патологии, но и с особенностями поведенческих моделей студента, приобретенных уже в процессе обучения при взаимодействии в новом микросоциуме - студенческой группе, курсе и т. д. [24, с. 1443; 25, с. 36]. Негативные поведенческие шаблоны и привычки, по различным данным, имеют от 40 до 72 \% студентов. Из наиболее часто встречающихся можно назвать: курение, употребление алкоголя, «энергетиков», эпизоды приема психоактивных веществ, транквилизаторов, анксиолитиков, постоянное и грубое нарушение распорядка дня, промискуитет, зависимость от социальных сетей и т. д. Отсутствие регулярных физических тренировочных нагрузок отмечают до 80 \% студентов университетов, в том числе медицинских $[17$, с. $82-84 ; 18$, с. $127 ; 19$, с. $155 ; 26$, с. $78-84]$.

Здоровьесберегающее поведение (ЗСП) социология здоровья рассматривает как осознанные действия по формированию и принятию поведенческих решений, направленных на сохранение и упрочение здоровья, а также реализацию этих решений. [27, с. 115]. Судя по объему и качеству проводимых исследований, интерес экспертного сообщества к проблемам студенческого здоровья и ЗСП в настоящее время высок. Однако инструментарий, критерии и нормативы оценки поведения студентов в отношении своего здоровья в настоящее время не унифицированы, а большинство работ направлено на изучение поведенческих моделей, связанных со сравнительно узким спектром факторов влияния [28, с. 68-70; 29, с. 400-401].

В предыдущем исследовании нами была предпринята попытка оценить возможно более широкий спектр факторов, ассоциированных с поведенческими шаблонами в отношении здоровья. В процессе работы мы выявили ряд параметров, наиболее сильно коррелирующих с качеством жизни, связанным со здоровьем и индексом коморбидности Чарлсона - показателем текущего состояния здоровья, рассчитывае- 
мым по количеству и тяжести заболеваний, а также по возрасту обследуемого. Однако неизученным остался вопрос взаимосвязи негативных средовых факторов с асоциальными, деструктивными поведенческими стереотипами в свете адаптации студентов к новой микросоциальной среде и научения адаптационному поведению, а также вопрос выбора и «копирования» студентами поведенческих моделей среди значимых других [30, с. 80-83]. В то же время подобные изыскания позволили бы сформулировать модель, описывающую социальный процесс приспособления студентов медицинских университетов к меняющимся условиям образовательного пространства с точки зрения воздействия негативных средовых факторов на поведение и состояние здоровья, и, возможно, выработать рекомендации по снижению уровня подобных влияний.

Исходя из этих предпосылок, мы определили следующую цель данной работы: провести анализ снижения эффективности социального процесса - формирования рационального здоровьесберегающего поведения под влиянием негативных средовых факторов среди студентов медицинских университетов

\section{Методы}

Эмпирическая часть исследования проведена с 01.10.2018 по 01.06.2019 года в Тихоокеанском государственном медицинском университете (ТГМУ) и Дальневосточном федеральном университете (ДВФУ) в соответствии с принципами стратифицированной рандомизации. При формировании выборки учитывалась необходимость равного гендерного и пропорционального возрастного представительства, расчет ее объема проводился исходя из дисперсии исследуемых признаков в ранее проведенных подобных исследованиях. В итоге в выборку вошли 827 студентов медицинских специальностей: 411 девушек (49,7\%; средний возраст - 21,5 лет) и 416 юношей (50,3 \%; средний возраст - 21,6 лет). Студентов, обучающихся на младших (1-3) курсах, оказалось 398 человек (48,1 \%), соответственно, на старших (4-6) 429 (51,8 \%). В городском округе до поступления в университет проживали 617 человек (74,6 \%), в сельской местности - 210 (25,4 \%). Во время проведения исследования проживали в университетских кампусах 688 человек (83,2 \%), 101 (12,2 \%) студент дома, еще 38 (4,5\%) заявили, что живут на съемных квартирах. Отклик составил $93,3 \%$.

В основу собранного информационного массива легли данные, полученные с использованием анкеты самооценки качества жизни студента вуза [31, с. 57-58], дополненной и уточненной авторами [30, с. 80-83]. Анкета состоит из 56 вопросов, сгруппированных в домены и связанных с социально-экономическими, демографическими, психологическими и другими факторами, влияющими на поведенческие стереотипы в отношении здоровья. При ответе на вопросы студентам предлагалось оценить наличие позитивного поведенческого стереотипа от 0 (минимальное, «негативное» значение) до 5 (максимально позитивный ответ). Ряд вопросов, касающихся негативных привычек оценивался по этой же шкале, но в «обратном» порядке, то есть отсутствие такой привычки расценивалось как позитивный стереотип (например, некурящим студентам предлагалось оценивать частоту курения в 5 баллов - как максимально позитивный ответ). Порядок работы с такими вопросами подробно разъяснялся респондентам, а также указывался в подстрочнике анкеты, сами вопросы для облегчения восприятия обозначались знаком *. 
В предыдущих исследованиях мы провели корреляционный анализ, позволивший выявить ряд наиболее значимых средовых факторов, в том числе негативных, взаимосвязанных с успеваемостью и объективным состоянием здоровья студентов [26; 24, с. 83-89; 30, с. 79-80]. Однако их влияние на поведенческие стереотипы в отношении здоровья осталось за рамками проведенной ранее работы. В настоящем исследовании мы предприняли попытку анализа такой взаимосвязи. Для сбора информации о поведенческих стандартах и шаблонах анкета самооценки качества жизни студента вуза была также дополнена отдельным блоком вопросов относительно практикуемых студентами стереотипов поведения, также был внесен вопрос о значимых других, являющихся для студентов возможными ориентирами для подражания, поведенческие стереотипы которых являются «модельными», установочными при формировании собственных поступков и алгоритма поведения в целом $[32$, с. $579 ; 33$, с. $65 ; 34$, с. $12-15 ; 35$, с. $21-23]$.

Статистическая значимость корреляции между средними значениями переменных определялась при расчете коэффициента Спирмена. Сила взаимосвязи связи переменных расценивалась как высокая в диапазоне значений коэффициента $\mathrm{R}=0,8-$ 1.0, как среднего уровня - при $\mathrm{R}=0,5-0,7$. Значимость отсутствующих переменных для сравнительного анализа определялась по значениям теста Вальда.

\section{Результаты}

В 31 (3,7 \%) случае данные оказались неполными или неинтерпретируемыми.

Неполный набор данных был связан как с ошибками при заполнении анкет, так и с отказом 11 студентов, согласившихся на участие в исследовании, отвечать на конкретный вопрос в анкете. Сопоставление средних значений переменных по методу Вальда позволило подтвердить гипотезу об отсутствии статистической значимости отсутствующих данных для сравнительного анализа. Не было также обнаружено статистически значимых различий между средними значениями показателей у студентов младших и старших курсов, у студентов мужского и женского пола, за ис-

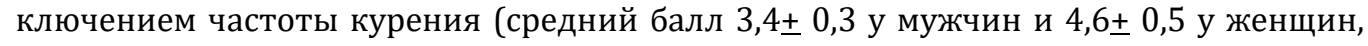
$\mathrm{p} \leq 0,05$, оценка показателя реверсивная).

При количественной самооценке поведенческих шаблонов были получены следующие результаты. Средняя суммарная оценка студентами соблюдения режима сна и бодрствования составила 3,4 балла, наличие вредных привычек - 3,3 балла (реверсивная оценка), выполнение основных гигиенических правил - 4,5, физическое самосовершенствование - 2,1 балла, признаки профессионального выгорания - 1,5 (реверсивная оценка), выполнение назначений врача при заболевании - 2,3, отказ от самолечения - 2,9, самооценка и самоанализ физического и психологического статуса - 1,3, копирование позитивных/негативных поведенческих стереотипов $2,9 / 2,1$, самооценка патологических симптомов при их возникновении - 3,9, промискуитет - 0,9 баллов. Итоговая средняя суммарная самооценка составила 2,6 балла.

Средняя суммарная переменная, количественно описывающая негативные поведенческие стереотипы, оказалась наиболее сильно взаимосвязана с нарушением регулярного и рационального питания $(\mathrm{r}=0,91, \mathrm{p} \leq 0,05)$, отсутствием комфортных условий проживания $(\mathrm{r}=0,77, \mathrm{p} \leq 0,05)$ и обучения $(\mathrm{r}=0,67, \mathrm{p} \leq 0,05)$, недоступности по различным причинам спортивных учреждений для занятия физическими упражнениями $(\mathrm{r}=0,72, \mathrm{p} \leq 0,01)$ (рис. 1$)$. 


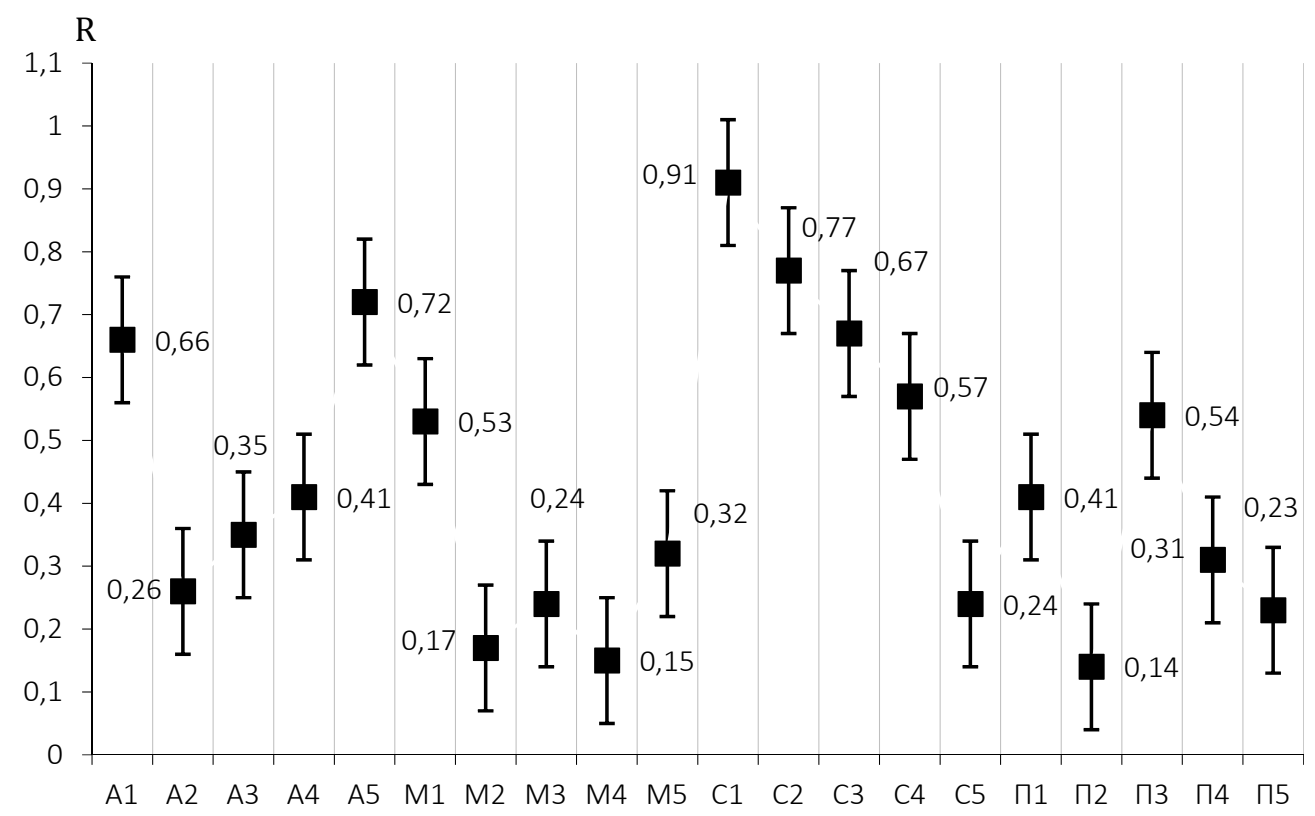

Рисунок 1. Корреляция описательных переменных, характеризующих негативные факторы среды и композитного показателя негативных поведенческих стереотипов в отношении здоровья у студентов медицинских специальностей ( $\mathrm{n}=827)$

Оа рисунке:

Административные: отсутствие

A1 комфортного расписания

A2 доступного изложения учебного материала

АЗ достаточного методического и

инструментального обеспечения занятий

A4 возможностей для самообразования

A5 возможностей для занятий физическими

упражнениями

Медицинские: отсутствие

M1 доступной квалифицированной

медицинской помощи

M2 возможности диспансеризации

Мз возможностей для приобретения необходимых лекарств

M4 информированности о заболеваниях

M5 возможностей для использования

медицинской контрацепции

\section{Средовые факторы}

Социально-бытовые и экономические: отсутствие

C1 регулярного и рационального питания

C2 комфортных условий проживания

С3 комфортных условий обучения

С4 достаточного личного дохода

С5 транспортной доступности университета 
Корреляционная зависимость средней степени была установлена между суммарной переменной и количественной оценкой фактора отсутствия удобного, учитывающего потребность в отдыхе и обеденный перерыв расписания $(\mathrm{r}=0,66, \mathrm{p} \leq 0,05)$, уровнем личного дохода / материального достатка $(\mathrm{r}=0,57, \mathrm{p} \leq 0,05)$, возможностью творческой самореализации ( $\mathrm{r}=0,54, \mathrm{p} \leq 0,01)$, слабой доступностью квалифицированной медицинской помощи $(\mathrm{r}=0,53, \mathrm{p} \leq 0,05)$. Прочие факторы оказались слабо взаимосвязаны с поведенческими стереотипами студентов.

Анализ результатов анкетирования позволил установить, что при формировании собственного поведенческого рисунка 47,4 \% студентов ориентируются на лиц, с которыми они поддерживают дружеские отношения в университете, и 33,4 \% вне университета. В качестве примера для подражания 20,5 \% студентов назвали преподавателей университета, 15,5 \% - лидеров мнений в студенческой среде, с которыми они лично не знакомы, 13,8 \% - родителей, 12,8 \% - известных медийных личностей, 3,5 \% - представителей администрации учебного заведения, другие ответы дали 4,6\% респондентов. Вопрос предполагал возможность более 1 ответа (сумма более 100 \%). Таким образом, согласно данным опроса, подавляющее большинство студентов называют в качестве ориентира в поведении, касающемся здоровья и здоровьесбережения, университетских и школьных друзей (в сумме 80,8 \%).

\section{Обсуждение}

Анализ полученных эмпирических данных позволил установить, что наиболее сильные корреляционные зависимости со средней суммарной переменной, количественно описывающей негативные поведенческие стереотипы в отношении здоровья, отмечаются для таких средовых факторов, как нарушение регулярного полноценного питания, отсутствие комфортных условий проживания и обучения, недоступность по различным причинам спортивных учреждений, тренажерных залов, бассейнов для занятия физическими упражнениями. Корреляционная зависимость средней степени была отмечена с такими факторами, как отсутствие комфортного, обеспечивающего потребность в отдыхе расписания, уровень индивидуального дохода / материального достатка, возможность творческой самореализации, слабая доступность квалифицированной медицинской помощи.

Полученный результат с позиций структурно-функционального подхода и формирования двухкомпонентной модели: средовые факторы - поведение, на наш взгляд, в значительной мере можно интерпретировать как проявление влияния фоновой институциональной структуры образовательного пространства университета на поведенческий рисунок студентов и шире на реализацию основной социальной функции учащихся - процесса приобретения профессиональных знаний, навыков и компетенций [24, с. 1443]. Суммарная оценка поведенческих стандартов показала, что здоровьесберегающий компонент в поведении студентов представлен достаточно слабо. Итоговая суммарная оценка составила 2,6 балла, наиболее «проблемными» опциями оказались отсутствие самооценки и самоанализа физического и психологического статуса, наличие вредных привычек, невыполнение назначений врача при заболевании, отсутствие физического самосовершенствования, невыполнение рационального режима сна/бодрствования и работы/отдыха.

Данные исследования влияния факторов среды оказались в целом вполне ожидаемыми и подтвердили разрозненные результаты исследований других авторских коллективов. Так, отсутствие нормального питания, некомфортная образовательная 
и бытовая среда, отсутствие условий для активного отдыха (часто при наличии собственных спортивных сооружений и приспособлений в кампусе), неудобное расписание, материальные проблемы, отсутствие эффективной рекреационной среды и условий для общения «оффлайн», недоступность своевременной квалифицированной медицинской помощи в той или иной мере описываются многими авторами, хотя в большинстве случаев и в виде предположений, не подкрепленных достаточной эмпирической базой. В то же время мы не обнаружили среди значимых факторов, негативно влияющих на поведение в отношении здоровья, отсутствие возможностей для прохождения полноценной диспансеризации и приобретения необходимых лекарств в случае заболевания. То есть, с одной стороны, студенты указывают на наличие проблемы, с другой - мы не видим устойчивой взаимосвязи этих негативных факторов с поведенческим рисунком. Возможно, это связано с тем, что, несмотря на высокую хроническую соматическую заболеваемость, в силу высоких адаптационных возможностей и резервов, свойственных данному возрасту, симптоматика хронических болезней проявляется у студентов достаточно скудно [28, с. 70-72; 36, c. $252 ; 37$, с.277]. Кроме того, высокий уровень информационной загруженности, чрезвычайно активная коммуникация, повышенное психоэмоциональное и когнитивное напряжение, характерное для всего периода обучения в университете, предполагает «вытеснение» на периферию сознания самооценки поведения, активного использования рефлексии, самоанализа, формирование «стихийного» поведенческого рисунка, во многом определяемого непосредственным влиянием социальнобытовых, организационных, административных и иных средовых факторов. Вероятно, поэтому известные модели убеждений о здоровье, мотивации-информациинавыков, запланированного поведения, субъективной ожидаемой полезности, мотивации защиты в полной мере не могут служить удовлетворительными конструктами для интерпретации мотиваций поведения в отношении здоровья для исследуемой когорты.

Подводя итоги, можно сказать следующее. Используемая в рамках структурнофункционального подхода двухкомпонентная модель процесса формирования поведения в отношении здоровья позволила установить, что средняя суммарная переменная, количественно описывающая негативные поведенческие стереотипы, имеет сильную корреляцию с рядом социально-экономических факторов университетской образовательной среды. В то же время мы можем предположить, что в связи с высоким уровнем психоэмоциональных и физических нагрузок, выраженными компенсаторными возможностями и связанной с этими особенностями слабой склонностью к рефлексии имеющиеся модели убеждений о здоровье, мотивации-информациинавыков, запланированного поведения, субъективной ожидаемой полезности, мотивации защиты, в разной степени применимые к популяции в целом, у исследуемой социальной и возрастной категории - студентов медицинских университетов - могут иметь ограниченное применение и слабо отражать механизмы формирования поведенческих стратегий.

Предварительный анализ подражательной активности студентов при выборе поведенческой стратегии в отношении здоровья показал, что большинство студентов отмечают в качестве образов копирования поведение друзей, преподавателей университета, в меньшей степени - лидеров мнений и родителей. Данное пилотное исследование может стать основанием для более углубленного изучения процессов 
формирования поведенческих стратегий в отношении здоровья и анализа полученных результатов в свете представлений о социально приемлемом поведении личности как результате научения и коммуникативном воздействии на личность.

\section{Конфликт интересов}

Авторы заявляют об отсутствии конфликта интересов.

\section{Ссылки / References}

1. Содержательные и организационные аспекты формирования навыков здорового образа жизни у студентов вузов / А. Э. Болотин, О. В. Миронова, С. М. Лукина, Л. В. Ярчиковская // Теория и практика физической культуры. 2016. № 6. С. 18-20.

2. Донченко В. И. Структурная модель обучения студентов-медиков здоровьесберегающим технологиям // Концепт. 2015. № 10 (октябрь). С. 111-115.

3. Рощина Я. М. Социальная дифференциация и образовательные стратегии российских студентов и школьников: информационный бюллетень. М.: ГУ-ВШЭ, 2007.

4. Бандура А. Теория социального научения. СПб.: Евразия, 2000. 320 с.

5. Мертон Р. К. Социальная теория и социальная структура // Социологические исследования. 1992. № 2-4. С. 118-124.

6. Пинкер С. Субстанция мышления: язык как окно в человеческую природу. Пер. с англ. Изд. 2-е, испр. 2016. 560 с.

7. Ковалёв А. Д. Формирование теории действия Тэлкотта Парсонса // История теоретической социологии. В 4-х тт. Т. 3. М.: Канон, 1997, С. 150-179.

8. Х Хабермас Ю. Теория коммуникативного действия (Фрагменты). Пер. А. Б. Рахманова // Личность. Культура. Общество. 2004. № 1 (21). С. 303-312.

9. Рассказова Е. И. Модели стадий изменения поведения в психологии здоровья: возможности и ограничения // Вестник Московского университета. Серия 14. Психология. 2014. № 4. С. 102-119.

10. Мельник С. Н. Психология личности. Владивосток: Дальневосточный государственный университет, 2004. 97 с.

11. Рассказова Е. И., Иванова Т. Ю. Мотивационные модели поведения, связанного со здоровьем: проблема «разрыва» между намерением и действием // Психология. Журнал Высшей школы экономики. 2015. Т. 12. № 1. С. 105-130.

12. Цветкова Л. А. Социально-психологические теории формирования аддикций // Вестник Московского университета. Серия 14. Психология. 2011. № 2. С. 166-178.

13. Каплыгина И. И. Теоретические аспекты исследования воздействия информационнообразовательного пространства на здоровье и поведение человека // Научные ведомости. Серия Гуманитарные науки. 2016. № 14 (235). С. 143-150.

14. Кирякова Н. И. Теория ожидаемой полезности // Академия. 2015. № 3 (3). С. 1-4.

15. Роджерс Р. В. Мета-анализ исследований по теории мотивации защиты // Журнал прикладной социальной психологии. 2000. № 30 (2). С. 407-429. 
16. Рассказова, Е. И. Психологические факторы поведения, связанного со здоровьем: на пути к интегративной модели // Теоретическая и экспериментальная психология. 2016. T. 9, № 4. С. 124-139.

17. Бруснева В. В., Клименко Т. В. Значимые факторы и условия жизни, влияющие и формирующие состояние здоровья студенческой молодежи города Ставрополя // Медицинский вестник Северного Кавказа. 2012. № 3. С. 82-86.

18. Гареева И. А., Соболевская Т. В. Роль социальных барьеров в формировании стратегий поведения в отношении здоровья у студентов // Материалы секционных заседаний 56-й студенческой научно-практической конференции ТОГУ: в 2 т. Т. 2. Хабаровск: Изд-во ТОГУ, 2016. С. 127-130.

19. Джураева Н. С. Здоровье, здоровьесберегающее поведение и качество жизни студентов // Модели, системы, сети в экон. техн. природе и о-ве. 2014. № 3. С. 155-160.

20. Улумбекова В. Г., Калашникова А. В. Факты о бюджете здравоохранения РФ на 20182020 года // ОРГЗДРАВ: новости, мнения, обучение. Вестник ВШОУЗ. 2019. №4. С. 17-20.

21. Алексеенко С. Н., Дробот Е. В. Категории жизнестойкости и качества жизни у студентов медицинского ВУЗа в сопряженности с самооценкой здоровья // Земской врач. 2014. № 2 (23). C. 41-44.

22. Новохатская Э. А., Яковлева Т. П., Калитина М. А. Заболеваемость студентов, обусловленная характером питания в современных условиях обучения // Проблемы социальной гигиены и история медицины. 2017. № 5. С. 281-285.

23. Гареева И. А. Неравенства в социальном пространстве здравоохранения // Трансформация человеческого потенциала в контексте столетия: материалы междунар. науч.-практ. конф. в рамках III Всерос. науч. форума «Наука будущего - наука молодых». Нижний Новгород 14-15 сент. 2017 г.: в 2 т. Т. 2. Н. Новгород, 2017. С. 16-19.

24. Киенко Т. С. Институциональные и не-институциональные факторы формирования здоровьесберегающего поведения // Современные проблемы науки и образования. 2015. № 1-1. C. 1443.

25. Бакаев В. В., Болотин А. Э. Показатели готовности студентов к здоровьесберегающему поведению // Ученые записки университета им. П. Ф. Лесгафта. 2013. № 12 (106). C. 36-39.

26. Новый индекс здоровьесберегающего поведения / В. В. Кузнецов, К. В. Косилов, Р. А. Байрамов, Е. К. Косилова (Федорищева), Н. И. Ющенко, Е. А. Смирнов // Медицинское образование и профессиональное развитие. 2019. Т. 10 (4). С. 76-92.

27. Ж Журавлева И. В., Иванова Л. Ю., Ивахненко Г. А. Студенты: поведенческие риски и ценностные ориентации в отношении здоровья // Вестник института социологии. 2012. № 6. С. 113-129.

28. Биловус В. К., Минасян Л. А. Установки молодежи на здоровьесберегающее поведение // Создание условий в учебных заведениях высшего профессионального образования, обеспечивающих охрану и укрепление физического, психологического и социального здоровья обучающихся, формирование устойчивой мотивации на здоровье и здоровый образ жизни: мат. межвуз. науч.-практ. конференции. Шахты, 2008. С. 68-79.

29. Лепихина Т. Л., Карпович Ю. В. Анализ факторов, формирующих здоровьесберегающее поведение работников // Фундаментальные исследования. 2014. № 8-2. С. 400-403. 
30. Федорищева Е. К. Комплексная оценка здоровьесберегающего поведения студентов медицинских специальностей и направления его оптимизации // Власть и управление на Востоке России. 2019. № 3 (88). С. 97-116.

31. Поздеева Т. В. Научное обоснование концепции и организационной модели формирования здоровьесберегающего поведения студенческой молодежи: дис. ... докт. мед. наук: 14.00.33: защищена 09.09.2008 / Поздеева Татьяна Васильевна. М., 2008. 340 с.

32. Корниенко Д. С., Козлов А. И., Отавина М. Л. Взаимосвязь самооценок здоровья и психологического благополучия у практически здоровых и имеющих хронические заболевания молодых людей // Гигиена и санитария. 2016. № 6. С. 577-581.

33. Скрининг ресурсов здоровья студентов и формирование внутри-вузовской профилактической среды: клинические, образовательные и воспитательнопедагогические аспекты / М. Е. Евсевьева, В. И. Кошель, М. В. Еремин и др. // Медицинский вестник Северного Кавказа. 2015. № 1. С. 64-69.

34. Здоровье и поведение школьников: Социально-педагогический мониторинг здоровья, физической активности и образа жизни школьников: Уральский федеральный округ / Сост. А. И. Федоров, С. Б. Шарманова. Челябинск: УралГАФК, ЧГНОЦ УрО РАО, 2004. 88 с.

35. Борисова Л. М., Белокурова Е. С., Лопатин С. А. Здоровьесберегающие технологии как профилактические меры по сохранению и укреплению здоровья студентов вузов // Безопасность жизнедеятельности. 2014. № 8. С. 21-26.

36. Здоровье студентов: социологический анализ / Отв. ред. И. В. Журавлева. Институт социологии РАН. М., 2012. С. 252-257.

37. Гареева И. А. Социальные барьеры современной системы здравоохранения // Современные проблемы экономического развития предприятий, отраслей, комплексов, территорий: материалы междунар. науч.-практ. конф. (Хабаровск, 25 апр. 2016 г.): в 2 т. Т. 2. Хабаровск: Изд-во ТОГУ, 2016. С. 275-278.

38. Х Хабермас Ю. Проблематика понимания смысла в социальных науках // Социологическое обозрение. 2008. № 7(3).

39. Х Хабермас Ю. Теория рационализации Макса Вебера // Социологическое обозрение. 2009. № 8(3).

40. Рассказова Е. И., Тхостов А. Ш., Гульдан В. В. Способы заботы о здоровье и соматические жалобы в норме: роль представлений и роль действий // Психологические исследования. 2016. № 9(50). С. 4.

41. Бобылева О. В. Состояние здоровья студенческой молодежи как социальноэкологическая проблема // Вестник ТГУ. 2013. Т. 18. Вып. 3. С. 852-854. 